\begin{abstract}
Recent work in applied linguistics, sociolinguistics and language education has called for the 'return' of class in the critical examination of the role of language in society and education under the organizing logic of capitalist globalization. Nevertheless, while the restoration of class as a core aspect of sociolinguistic analysis is much welcome, it has also come with its own ideological erasures: the disappearance of colonialism and coloniality. Thus, this paper aims to, first, tackle the general erasure of class in intellectual movements in the humanities and social sciences for the past few decades, then second, demonstrate how such erasure in fact involves the decoupling of class and colonialism in research on the politics of Englishes in the Philippines, before introducing the concept of Unequal Englishes (Tupas, 2015; Tupas \& Salonga, 2016) as a way to address directly such politics.
\end{abstract}

\title{
Other Language Abstract
}

Ro mga bag-o nga kasueatan sa mga imbestigasyon it lengwahe hay nagatawag sa pagbalik ko paggamit it konsepto nga 'class' sa pagbinagbinag it mayad sa papel it lenguaje sa sosyodad ag edukasyon sa idaeom it organisado nga katinuan sa capitalismo nga globalisasyon. Pero samtang nga ro pagbalik ngara it 'class' sa pagbinagbinag it lengwahe sa sosyodad hay dapat nga suportahan, may problema man sa paggamit it konsepto ngara: ro pagkapaea ag pagkaduea it kolonyalismo ag ro mga impluwensiya it kolonyalismo makaron. Ngani ro papel ngara hay maga handum nga, una, makabais-bais anay bahin sa pag paea it 'class' sa humanidades ag social sciences, tapos, pangaywa, ipakita nga rondayang pagpaea ngara hay nangin kaibahan ro pagputoe it koneksion it 'class' sa kolonyalismo sa mga risirts sa pulitika it mga ibat-iba nga 
klase nga Ingles, bago ipakita ro konsepto, Unequal Englishes, bale isaea nga paagi agud maintindihan ro rondaya ngara nga pulitika

\section{Introduction}

The material foundation of social class is associated broadly with socioeconomic tiers into which groups of people are slotted based on their income, wealth, purchasing power, educational attainment, social memberships and other measurable social factors, and for some differentiated embodied dispositions and experiences (Bourdieu, 1979; Vincent \& Ball, 2007) formed and framed persistently by capitalist economic agendas and practices. The durability of the materiality of social class is essentially the reason why several scholars in sociolinguistics, applied linguistics and other related fields have recently called for the 'return' of class as a key lens in the study of society, and more specifically the study of language in society (Block, 2014; Butler, Sayer, \& Huang, 2018), after having been sidelined or ignored by the 'cultural turn' in the field.

Nevertheless, this paper argues that central to reclaiming class in the study of language in society is to also foreground the imbrication of class and colonialism (including its enduring legacies today). Early sociolinguistic investigations of class and capitalism provided marginal attention to their entanglement with imperialism, while current literature on class in sociolinguistics (and related fields like applied linguistics) does not fully address this imbrication despite some efforts to surface it in the analyses (Block, 2014; Butler, Sayer, \& Huang, 2018). In other words, the restoration of class as a core aspect of sociolinguistic analysis has also come with its own ideological erasures: the disappearance of 'colonialism and its replicants' (or 
coloniality) (Moraña, Dussel, \& Jáuregui, 2008) - in such a class-centred reconfiguration of sociolinguistic analysis.

In its general sense, colonialism refers to conditions and acts of direct subjugation of a particular nation, territory and/or people by another country through the disruption or imposition of political and cultural structures of governance and rule. Formal structures of colonial governance were purportedly discontinued after political power was turned over back to erstwhile subjugated local populations. However, colonial conditions, practices and ideologies prevalent in the local people's daily lives, including the administering of so-called 'postcolonial' leadership, remain deeply rooted in the way local people live and govern their lives today (Schirmer and Shalom, 1987). This is what some refer to as the coloniality of life today (Quijano, 2007): our everyday life is saturated with replicants of colonialism or those conditions, practices and ideologies which have survived colonialism itself and continue to shape and regulate people's lives today (San Juan, 2000).

To support this paper's argument about the imbrication of class and colonialism, the case of the study of the pluralization of English in the Philippines will be used. The literature on English in the country and, for that matter, on colonial languages, has shown how these languages have contributed to the stratification of former colonial societies, but unlike some literature which has divested these languages of their colonial rootedness and entanglements, presumably because of their emancipatory role in world markets today, this paper takes the position that the role of these languages, and English in particular, in sustaining social stratification in former colonies is an enduring legacy of colonialism. English has been intimately bound up with colonial designs of subjugation - or what Sergio Bagú calls “omnipresent violence" of colonial rule (in Moraña, Dussel, \& Jáuregui, 2008, p. 2) - which have resulted in 
particular changes in class formations in society. How English has been entangled in the (re)making and preservation of the Philippine elites or caciques and colonially-induced social class structure (Anderson, 1998) and, more specifically, how the language continues to be implicated in the politics of class and racially-motivated colonial ideologies among Filipino call centre agents, are some specific examples of how the class-colonialism imbrication cannot be ignored in class-based analyses of language use today. Coloniality remains to be "the most general form of domination in the world today" (Quijano, 2007, p. 170).

Thus, this paper aims to, first, tackle the general erasure of class in intellectual movements in the humanities and social sciences for the past few decades, then second, demonstrate how such erasure in fact involves the decoupling of class and colonialism in research on the politics of Englishes in the Philippines, before introducing the concept of Unequal Englishes (Tupas, 215; Tupas \& Salonga, 2016) as a way to address directly such politics. The systematic pluralization and localization of English under conditions of capitalist globalization have not only resulted in the emergence of many Englishes in the world; they have, more crucially, generated unequally valued and stratifying Englishes through the combined power of capital and the enduring colonial structures and ideologies within which the accumulation of capital is deeply embedded.

\section{The erasure of social class}

This paper responds to what many scholars in recent years have observed both in society in general and in applied linguistics, sociolinguistics and related fields in particular: "a generalized disengagement from and erasure of class" (Block, 2014, p. 170, italics as original). 
Block rightfully argues that "social class should figure as a key construct in research being carried out" (p. 171). In critically examining work on the pluralization of English today, this paper also argues that social class dimensions of Englishes are inextricably linked with the enduring structures and ideologies of colonialism. In recent years, according to Block (2014), "there has been something of a shift away from social class in terms of its importance as a construct and in some cases outright erasure" (p. 73). Block is specifically referring in this statement to the broad field of sociolinguistics, noting further that this was in fact not the case among early sociolinguists (e.g., Hymes, Labov, Bernstein) who were drawn towards the construct of social class in their studies of the social life of language use. The same observation about the marginalization or erasure of social class also applies to other areas in language studies such as bi/multilingual research, literacy research, second language acquisition and learning, and TESOL and language education (Block, 2014; Butler et al., 2018; Murphy, 2018; Song, 2018; Sayer, 2018; Rampton, 2010), as well as other related fields such as sociology of education (Ghaill, 1996; Thrupp, 2001), and sociology of work and family (Atkinson, 2007; Bograd, 1999; Williams et al., 2013). Ramanathan and Morgan (2009), for example, lament the general blindness of the field of TESOL to issues of class; Butler et al. (2018) note that social class in language education research in general has received "scant attention" (p. 1). As mentioned at the start of the paper, the sidestepping or erasure of class is part of a general intellectual trend in academia which privileges the problem of culture and identity over the problem of structure and political economy. Thus, generally speaking, the study of colonialism, globalization and capitalism through the lens of culture: 
...has resulted in a dissociation of questions of culture and cultural identity from the structures of capitalism, shifting the grounds for discourse to the encounter between the colonizer and the colonized, unmediated by the structures of political economy within which questions of culture had been subsumed earlier (Dirlik, 2002, p. 432).

Moreover, the focus on culture supposedly allows scholars since the 1980s - from postmodernism and globalization theory to complexity theory - to align themselves with "the view that the present is simply too fluid, too transient and too awash with turbulent global scapes, mobilities or networks to be comprehended with the static and clunky ontological categories of the past" (Atkinson, 2007, p. 363). Instead of (re)structurations of social relations and individual lives (Féliz, 2016; Lazarato, 2009), the world has been viewed as constitutive of people engaged in perpetual mobilities (Urry, 2003), liquidness (Bauman, 2000) and identity border crossings (Thompson, 1999) through a wide array of lenses such as hybridization, pluralization, localization, and appropriation. This has led to in-betweeness of cultural identities and experiences, agency and resistance of the erstwhile subjugated people and, referring to language use in particular, "selecting, mixing, stylizing, truncating, and bending linguistic codes and expectations" (Kubota, 2015, p. 21). Thus, social class seemingly has died and could no longer function as a key construct in understanding the world (Urry, 2003), having become a 'zombie category' (Beck, 2002).

Consequently, recent calls to re-centre class in the analysis of the social life of language have argued that while contemporary life conditions have been reshaped by the structuring power of capitalist globalization, economic bases of social relations remain obstinately durable, 
perpetuating - if not exacerbating - poverty, economic inequality and social class divisions, as well as creating what many scholars refer to as the transnational capitalist class (Sklair, 1997; Robinson \& Harris, 2000). Thus, re-centring class places it squarely within the political economy of language which is essentially investigations of the role of language in the making, remaking and unmaking of social relationships within the political and economic matrix of global capitalism (Song, 2018; Block, 2014). That is, contemporary restructurations of relations between individuals, the state, and intra-state and inter-state political and economic institutions, are driven largely by the machinations of globalization within which the search and competition for capital remain globalization's key governing principle (Féliz, 2016; Sklair, 1997). The impact of capital on people's lives in this sense varies from individual to individual because capitalist globalization is structured in such a way that people with privileged access to capital and have the means to accumulate more will necessarily be in a greater (and freer) position to make decisions on all aspects of life (including use of language and access to quality education) than those furthest away from the promises and rewards of capital. In other words, there is no escaping the role of social class in the constitution of unequal relations between speakers and between groups of speakers because social relations are formed through the economic logic of capitalist globalization. In the more specific context of present-day learning of English, the social class of users and learners of English mediates and is mediated by the distribution of capital and the social mechanisms through which one can access it (Song, 2018; Park, 2010).

In the following section, I show how the erasure of social class comes into play in the study of English in the Philippines. However, I add that such erasure encompasses both class and coloniality for the reason that both are entangled with one another in the case of English in the 
country. Consequently, the call for the 'return' of class in the study of language in society also implicates the centrality of coloniality in the contemporary constitution of class.

\section{The erasure of social class and coloniality in the study of English in the Philippines}

One of the critical essays which appeared in the very first issue of the Journal of Contemporary Asia was Filipino historian Renato Constantino's (1970) 'The mis-education of the Filipino'. The essay takes a classic anti-colonial nationalist critique of the use of English in education as a key colonial tool to subjugate the Filipino people. First, through education in English, Filipinos became Americanized through and through: "In exchange for a smattering of English, we yielded our souls" (p. 23). And second, English became a socially-divisive language: "English became the wedge that separated the Filipinos from their past and later was to separate educated Filipinos from the masses of their countrymen" (p. 24). However, Constantino also suggests a third dimension to his critical essay which is generally not highlighted in early anticolonial nationalist critiques of language: the pluralizing yet socially stratifying proficiencies of English among Filipinos as a result of the imposition of English as medium of instruction to which only a select few have access in terms of quality of instruction: "Now we have a small group of men who can articulate their thoughts in English, a wider group who can read and speak in fairly comprehensible English and a great mass that hardly expresses itself in any language" (pp. 30-31).

When the United States (US) occupied the Philippines through the bloody PhilippineAmerican War of 1899-1902, the country had just emerged from its revolution against Spain which ruled the country for around 333 years. During the time of Spanish rule emerged the 
caciques, or specifically the local Chinese mestizos, who initially benefitted from commerce with Imperial China through the galleon trade with Manila as entrepôt, and then went on to disperse across the archipelago to engage in local trade (Anderson, 1998). During the first two decades of the $20^{\text {th }}$ century, the US implemented its colonizing strategy of benevolent assimilation by, first, co-opting the Spanish-speaking caciques in mediating conflicts between the colonial government and local communities and, second, introducing free basic education to all but mainly through English as medium of instruction (Schirmer and Shalom, 1987). These two interrelated American colonial machinations, in the words of Anderson (1998), "changed everything" (p. 10). On the one hand, such core political and educational infrastructures of benevolent assimilation perpetuated and, in fact, further enhanced the power of the caciques in Philippine society. Whereas they were wealthy and educated (in Spanish) during the latter decades of Spanish rule, American colonialism also helped them consolidate their political power base both in local and national politics, learning and endorsing English as the language of enlightenment and modernity, and becoming more powerful through colonial concessions in land ownership and control of natural resources. In fact, while not admitting it in public according to Anderson, the Filipino caciques did not really desire independence from the United States as this would threaten their exclusive access to the American market and colonially-mediated political power.

Thus, when the Philippines became independent, at least nominally, from the United States in 1946, the national and local political leadership was overwhelmingly dominated by the caciques who understandably did nothing substantial to dismantle colonial ideologies and structures of education and political governance, for example essentially keeping English as the primary language of education. Even when bilingual forms of education were put forward and 
established from 1974 to the present on educational and anti-colonial grounds, according to Hau and Tinio (2003) resistance to the Tagalog-based national language called 'Pilipino' or 'Filipino' as a medium of instruction took the shape of inter-elite regional rivalry: non-Tagalog local caciques were not really promoting their own languages to replace Tagalog but, instead, were rallying behind English in order to prevent Tagalog-speaking elites from having undue advantage in society through their proficiency in Tagalog. Despite speaking different local languages, the caciques would now be generally pro-English and speak the 'standard' variety of Philippine English despite their regionally-marked accents.

On the other hand, due to the universalization of basic education, the social reach of socalled 'good' English expanded and thus helped create new social groups, the biggest of which were the urban bourgeois and petty-bourgeois group composed of middle-level civil servants, doctors, nurses, engineers and teachers (among others). Espousing similar colonial ideologies about English as the language of capitalism and modernity, this group maintained that English was the key to global competitiveness such that by the mid-1980s already around one million Filipinos went overseas for work and settlement due to deteriorating political and economic conditions in the country. Many among this group, just like the caciques, would be highly educated (mainly in private schools or key state schools) and proficient in the English language, thus helping perpetuate the dominant place of English in society and education. They would soon differentiate themselves from the majority Philippine masa who were actually marginalized by the use of English since they could only afford to go to public schools where the teaching and learning of English were not up to standard.

The nationalist critique of English was precisely centered on the role of English, sociallystratified Englishes and colonial education as enablers of 'benevolent assimilation' in 
perpetuating cacique-like class relations in the country. However, alternative/reactionary postcolonial criticism through its culturalist lens would soon oversimplify - even distort - this thesis by glossing over the central role of colonialism (especially its structuring role) in the perpetuation and making of class relations through the imposition of the colonial language on Philippine life. Gonzalez (1976) provides what now would be recognized as a core culturalist postcolonial answer: "In thus appropriating English, Filipinos paradoxically have likewise emancipated themselves from American English and have taken the language for their own creative uses" (p. 453). Simply, "the Philippines has come into its own and has cut its umbilical cord" (p. 454). The central role of English in the maintenance of cacique-dominated class structure in the Philippines is ignored. According to Dirlik (2003), postcolonial criticism has by and large drawn attention away from political economy and questions about structural and systemic inequalities, to culture and questions about contingent and situational colonial encounters and postcolonial experiences where the colonized also 'localized', 'indigenized' and 'appropriated' colonial practices and ideologies, and this is exactly what Gonzalez has accomplished, using all these terms.

Research on the pluralization of English in the Philippines

Around the time Constantino's (1970) essay was published, another pioneering work on English in the Philippines also emerged. This was Llamson's (1969) book-length work, Standard Filipino English, one of the earliest empirically-driven books which aimed to prove - using formal linguistic tools - that English as it spread around the world was no longer a unitary, homogeneous language as was earlier believed and assumed. This work opened up a new vibrant 
space of research for the pluralization of English in the country (e.g., Castelo, 1972; Martinez, 1972; 1975; Gonzalez, 1976; Llamzon, 1986), foreshadowing for at least a decade the bourgeoning of work in the pluralization of English due to globalization (Pride, 1982; Platt et al., 1984; Kachru, 1986). Constantino (1970) and Llamson (1969) are practically making critical commentaries on English and education at the time, except that they are doing so through radically different lenses - Llamzon through quasi-objective linguistic analysis, and Constantino through a nationalist reading of political economy of language and education. Nevertheless, they share uncanny assumptions about English as a colonial language - first, that there exist subnational varieties of Philippine English, and that such varieties are distributed across groups of different classes. The main difference between the two scholars is that Llamson provides 'empirical' evidence for pluralized English in the country, choosing to describe linguistically the English of the privileged 'educated' Filipino elite without making any critical comment on why there is such an educated local variety of English as opposed to the unspoken 'un-educated' nonstandard ones in the first place. Simply, what counts as legitimate Filipino variety of English is one spoken by a small group of educated Filipinos. Constantino, on the other hand, makes references to unequal Englishes in early 'postcolonial' Philippines but explicitly argues that this class-shaped phenomenon is traceable to colonial structures of control, foremost of which is the technology of education through which English was imposed as the sole medium of instruction. Llamzon, in other words, provides empirical evidence for the localization and pluralization of English in the Philippines (to his credit, this was already a radical argument at the time), but his main and only focus is the distinct variety of English in the Philippines which he describes as 'educated', while Constantino problematizes the emergence of such an 'educated' variety of English as this is, to him, proof that the imposition of the English language has divided 
Philippine society along class lines. Against the masses of Filipinos who were rendered inarticulate in any language, English helped perpetuate the existence of the cacique class discussed earlier in the paper (Constantino, 1970, p. 30). Constantino's claim about the social exclusivity of a privileged variety of English has, in fact, been proven correct by linguists and sociologists of language themselves who have described English language use in the country in terms of a hierarchy of proficiencies or Englishes (see Bautista, 1982; Sibayan \& Gonzalez, 1996; Tayao, 2004; Tinio, 2013), with standard, 'educated' Philippine English spoken by an elite few, and other Philippine Englishes spoken by those occupying the 'outer' and 'peripheral' social classes of Philippine society (Salonga, 2015; Martin, 2014; Lorente, 2012; Gonzales, 2017). However, the largely descriptive work detailing the hierarchy of Philippine Englishes has generally not engaged with the class-ifying work of English and education in the country.

What we have seen, in fact, is that the ideological lineaments engendered by Llamzon's work have taken on a unique intellectual character in similar studies which flourished thereafter, leading then Singaporean sociolinguist Tay (1991) to suggest early on that the "Philippines has perhaps produced the most comprehensive research on an indigenized variety of English" in Southeast Asia (p. 323). It is unique because it has been configured by both its response to vigorous nationalist challenges - including mass-based national liberation movements, which were then consolidating as a critical force against the colluding forces of American neocolonialism, capitalist globalization and the Marcos dictatorship in the 1970s - to the language question in the country, as well as its gradual but eventual cooptation of the culturalist argument of postcolonial theorizing. In other words, empirical studies on the pluralization of English in the country have become the locus of the depoliticization of the language question even if by doing so such studies have become deeply enmeshed in the politics of language. First, 
such studies have deployed cultural appropriations of English - thus educated Philippine English - as justification for the continued dominant presence of English in the country. Under the premise of (educated) phonological (Martinez, 1975; Gonzalez \& Alberca, 1978), syntactic (Castelo, 1972; Alberca, 1978; Gonzalez, 1983), semantic (Gonzalez, 1986) and rhetorical (Marasigan, 1980; Bautista, 1982) innovations by Filipino speakers of English, scholars have argued for both the legitimacy of the unique features of Philippine English, as well as Filipinos' claim to ownership over their own use of English, thus making them no longer victims of linguistic and cultural imperialism. The general claim is that colonial English has given way to Philippine (anti-colonial) English, akin to what Kachru (1988; 1997) would later refer to as the two faces of English, with the colonial face of English (past) giving way to the postcolonial face (present).

In the process, the embeddedness of Philippine English in enduring colonial structures of relations where, to give one example, high proficiency in the language could only be observed among the small (and mostly urban) Filipino elite, was dismissed as a thing of the past. There was a lack of critical reflexivity demonstrated in the work considering the fact that what was then being legitimized as Philippine English was exclusively reserved only for the variety produced by so-called educated Filipinos. The colonially-induced structures of relations between different groups of Filipinos where only a small elite of educated Filipinos benefited greatly from the imposition of English as the sole medium of instruction, continue to shape English language use today, except that these neocolonial relations are preserved or sustained "on new grounds" (Heller, 2010, p. 103).

Coloniality and class in Unequal Englishes 
One example of the entanglement of social class and coloniality in the pluralization of English is the case of Philippine English speaking workers in call centers in the Philippines (Salonga, 2010; Salonga, 2015; Tupas \& Salonga, 2016). They work in an offshore industry sited in the Philippines, but owned largely by US-based companies servicing customers based in the US as well in search of new sources of capital and cheap labour, thus it taps into the ability of Filipinos to speak in English. Call center work is part of a "globalized outsourced movement" (Forey \& Lockwood, 2007, p. 309) which refers mainly to back office functions, support services and call centers which are put up overseas by companies domiciled mainly in the US, as well as the UK and Continental Europe, for cheaper costs of doing business while maintaining, if not improving, the quality of business provision and customer service. Call centers, therefore, are not only "canonical sites of the globalized new economy" (Heller, 2010, p. 108), but also "key language-centered economic spaces characteristic of the globalized new economy" (p. 103, italics supplied). The standard economic view of this phenomenon claims that it benefits both (US-based) corporate interests as well as the interests of countries where business services relocate (such as India and the Philippines), but this simplistic understanding of the link between corporate profits and national wealth "is misplaced on economic grounds, and is also ideological in its universalization of corporate interests" (Levy, 2005, p. 686). Savings on wages, for example, do not translate into increase in national income but they do help consolidate further wealth generation among a small group of shareholders; ideologically, corporate interests are conflated with the interests of everyone else in society (p. 689), thus masking the (neo)colonial nature of asymmetrical power relations between industrialized and developing countries which 
produce this new structure of profit generation in the global scale (Levy, 2005; Banerjee \& Linstead, 2001).

One of the core issues in outsourced call center work is the use of English by workers who generally use the language at least as a second or third language (Friginal, 2009; Forey \& Lockwood, 2007). Thus, the demand for a particular level of English proficiency positions the Filipino call center agents in complex ways which implicate local relations of power and colonial politics of capital accumulation. First, their ability to speak English in ways which are acceptable to industry standards positions them as privileged Filipino speakers since practically only $1 \%$ of Filipino graduates who apply to become agents in call centers in the country are deemed ready for such work, while a slightly higher 3-5\% of applicants eventually make it after going through some training in, for example, accent neutralization, having initially been deemed ill-equipped to handle call center work in English (Forey \& Lockwood, 2007; Salonga, 2015). Recall here what Constantino (1970) observed about the imposition of English and its class-ifying role in society. These Filipino agents typically come from relatively good universities or English-speaking families who have wide access to quality education, and are thus locked into class-shaped unequal relations between most other young Filipino graduates whose proficiency in English shuts them out of good-paying jobs in the country such as those available in the outsourcing call center industry. This is precisely the point argued by (Kleibert, 2015) in a study on academeindustry linkages in the Philippines and the challenges that go with such market-driven collaboration: "English language skills, combined with neutral accents and cultural understanding of the customers' host environment, are only prevalent among the highesteducated strata of Filipino society" (p. 112). The call center agents' Philippine English, in other words, is close enough to the desired American Standard English. In a hierarchy of Philippine 
Englishes, shown in the works of generations of Filipino scholars mentioned above, this variety of Philippine English is the 'educated' variety (Sibayan \& Gonzalez, 1996) which is implicated in unequal globally-shaped local structures of social relations. Positioned within the search of capital and other sources of savings through cheap(er) labour, the Filipino agents' Philippine English serves as a way to facilitate such global drive for greater profitability in the midst of extreme global competitiveness and, in the process, perpetuates the privileged status of the Filipino agents in Philippine society. In the words of Salonga (2015), “only particular kinds of people, usually those who are already privileged, given that they have been deemed to speak the desired variety of English, can take part in what the industry has to offer" (p. 139). For this group of people, thus, call centers represent "opportunity and access to globalization and white-collar jobs or at least economic opportunities that do not require massive labor migration" (Heller, 2010, p. 109).

However, these Filipino call center workers also complain about being ideologically positioned as 'non-native' speakers at work, always being reminded (through formal trainings, for example) that they need to 'neutralize' their Filipino accent in order to make themselves flexible and desirable call center agents. Similarly, they too are recipients of daily linguistic racism (see Padios, 2018) as many customers (mainly American), partly frustrated over anxieties about job losses because of outsourced work purportedly taking away their source of livelihood, and partly due to enduring standard language colonial ideologies, refuse to engage with them and ask for 'native English speaking' representatives instead. In other words, despite helping generate much needed corporate profits through 'educated' Philippine English, the Filipino agents continue to be positioned racially as inferior workers of the world by virtue of their being 'non-native' speakers of English. This perpetuates enduring colonial language ideologies about 
English which are continuously observed in the way 'non-native' English teachers are marginalized around the world, both institutionally (Braine, 2013) and through everyday discourses of individual people (Mahboob \& Golden, 2013).

Therefore, what we see in all this is that Philippine English speaking call center agents are bound up with both local class-based relations, with the call center serving as the new context where such relations are perpetuated. However, the broader new global configurations of capital accumulation continue to generate ideologies of Standard (American) English, linguistic racism and anxieties over job loss, thus resulting in Filipino call center agents being positioned as less than ideal - thus inferior - speakers of English, even if their good proficiency in the language is drawn upon as one key variable that sustains the presence and viability of outsourcing business companies. Thus, while the Philippines remains as a key supplier of English-speaking human labour which is both cheap and exploitative, and which thus has maintained its role as producer of 'servants' of capitalist globalization (Parreñas, 2001), the impact of outsourcing on Filipinos is uneven as these newer spaces of globalized work are open only to a particular group of young ‘educated’ English-speaking Filipinos.

Of course, the entanglements of class, language and colonialism in the Philippines cannot only be seen through the English language use of Filipino call center agents. The politics of English in call centers is inextricably linked with the political and ideological infrastructures of education as well which, despite genuine efforts in the past many decades to open up to several Philippine languages, remain fundamentally centered on the desire for English and the training of Filipino youth as workers of the world (Navera, 2018). With Filipinos viewed as 'valuable investments', educational and language policies, including (perhaps especially) government efforts to institutionalize new discourses and practices which legitimize Filipino servitude in the 
global scale (see Lorente's [2018] 'scripts of servitude' and Parreñas' [2001] 'servants of globalization'), have in recent years pursued global capital aimed to gloss over the coloniality of English, education and social class. However, in the past decade or so, several US-funded projects have proliferated across the Philippines, especially Mindanao with a sizable Filipino Muslim population, aimed at introducing native speaker-based English language proficiency training laboratories into formal tertiary curricula (Tabiola, 2015; Tabiola \& Lorente, 2017; Tupas \& Tabiola, 2017). The explicit aim of such initiatives has been to help improve the English language proficiency of new Filipino graduates to prepare them for the global market, but the broader context within which these initiatives are undertaken is the Philippine government's collusion with the United States' counter-insurgency efforts in its so-called war on terror. However, such educational initiatives sustain the stratifying work of education through training of Filipinos for particular kinds of jobs (call center agents, health care providers, seafarers, etc.) which demand different kinds of Englishes, thus placing Filipinos of different social class backgrounds in a hierarchy of employment opportunities and positions. Thus, four decades after Constantino's (1970) nationalist critique of the coloniality of English and education in the Philippines, his observations about the central role of such coloniality in the shaping of everyday Filipino life, as well as unequal class relations between Filipinos, remain fundamentally true.

\section{Conclusion}

There are a few points to make regarding the case of Unequal Englishes in call centers in the Philippines. First, the call centers serve as newer frontiers of global capitalism where cheap 
labour is extracted from Filipino workers who speak the 'educated' variety of Philippine English. In the process, call centers - in fact, all forms of outsourcing business - become new contexts for (re)configuring structures of social relations, as well as ideologies of language, race and identity. These structures and ideologies are embedded in the enduring and resilient configurations of colonialism and its replicants. On the one hand, Filipino call center agents' entry into the call center industry is fueled in the huge part by their ability to speak an acceptable variety of English by virtue of their access to good schools or their privileged family backgrounds. Thus, the call centers - while accumulating capital or earning savings for their mainly US-based shareholders also serve as spaces for the perpetuation of colonially-induced unequal social relations in the Philippines where a great majority of young Filipino students and graduates are shut out of the industry mainly because of their inability to speak 'educated' Philippine English. On the other hand, while this small group of Philippine English speaking agents may be deemed to benefit from outsourcing work, they also experience marginalization and racism in the workplace because of their Philippine 'accented' English. This is what Heller (2010) more broadly refers to as the "high price of the racialization and feminization used in the service of exploitation" (p. 109). The Filipinos are, in other words, treated as racially-inferior by virtue of their 'nonstandard' use of English. Call centers, in this sense, also serve as places where colonial ideologies of the superiority of 'native' speakers of English circulate to cement racially-defined relations between 'native' and 'non-native' speakers of English. Capitalist globalization remains unabated, thus so too are the ideologies of language and racial categorization that have come with it (Quijano, 2007).

Therefore, what we see here are the entanglements of capitalist globalization, coloniality of both local and global power relations, the proliferation of many Englishes, and class-shaped 
relations among speakers and non-speakers of Englishes. There is much to see in the role of social class in the politics of Englishes in the way call center work is configured through the mechanisms of global capital, but colonial inflections of social relations and the ideologies that circulate in and around the workplace also shape such politics in very critical ways. For at least four decades now, much has been lost in the way the globalization and pluralization of English have been examined and comprehended, thus recent calls to 'bring back' political economy, structure and social class in applied linguistics, sociolinguistics and language education are both timely and much welcome. However, the coloniality of the social life of language is a persistent reality, and thus must inform our understanding of how language use today continues to make, unmake and remake social relations and ideologies under conditions of capitalist globalization.

\section{References}

Abad, G. (1997). Standards in Philippine English: The writers' forum. In M. L. S. Bautista (ed.), English is an Asian Language (pp. 163-176). Sydney: The Macquarie Library Pty.

Benedict, A. (1998). Cacique democracy in the Philippines. New Left Review, 169, 3-33.

Ashcroft, G., Griffiths, G., and Tiffin, H. (1989). The Empire writes back: Theory and practice in post-colonial literatures. London: Routledge and Kegan Paul.

Atkinson, W. (2007). Beck, individualization and the death of class: a critique. The British Journal of Sociology, 58(3), 349-366.

Banerjee, S. B. \& Linstead, S. (2001). Globalization, multiculturalism and other fictions: Colonialism for the new millennium?' Organization, 8, 683-722.

Bauman, Z. (2000) Liquid modernity. Cambridge: Polity Press. 
Bautista, M. L. S. (1982). Yaya English. Philippine Englishes, 30, 377-394.

Beck, U. (2002). The cosmopolitan society and its enemies. Theory, Culture \& Society, 19(1-2), 17-44.

Bhatt, R. M. (2001). World Englishes. Annual Review of Anthropology, 30, 527-50.

Block, D. (2014). Social class in applied linguistics. Oxon and New York: Routledge.

Bograd, M. (1999). Strengthening domestic violence theories: Intersections of race, class, sexual orientation, and gender. Journal of Marital and Family therapy, 25(3), 275-289.

Bolton, K. (2010). Creativity and world Englishes. World Englishes, 29(4), 455-466.

Bourdieu, P. (1979) Distinction. Abingdon: Routledge

Braine, G. (1999). Non-native educators in English language teaching. Mahway, N.J \& London: Lawrence Erlbaum.

Brutt-Griffler, J. (1998). Conceptual questions in English as a world language. World Englishes, 17, 381-392.

Burke, P. (2009). Cultural hybridity. Cambridge: Polity Press.

Butler, Y. G., Sayer, P., \& Huang. B. (2018). Introduction: Social class/socioeconomic status and young learners of English as a global language. System, 73, 1-3.

Castelo, L. M. (1972). Verb usage in educated Filipino English. IRAL-International Review of Applied Linguistics in Language Teaching, 10(1-4), 153-166.

Constantino, R. (1970). The mis-education of the Filipino. Journal of Contemporary Asia, 1(1), 20-36.

Deleuze, G. \& Guattari, F. (1987). A thousand plateaus: Capitalism and schizophrenia (B. Massumi, trans.). Minneapolis: University of Minnesota.

Dirlik, A. (2003). Global modernity?: Modernity in an age of global capitalism. European 
Journal of Social Theory, 6(3), 275-292.

Dirlik, A. (2002). Rethinking colonialism: Globalization, postcolonialism, and the nation. Interventions: International Journal of Postcolonial Studies, 4(3), 428-448.

Féliz, M (2016). Transformations in Argentina's capitalist development since the neoliberal Age: Limits and possibilities of a peripheral development strategy. World Review of Political Economy, 7(3), 1-9.

Forey, G., \& Lockwood, J. (2007). "I'd love to put someone in jail for this": An initial investigation of English in the business processing outsourcing (BPO) industry. English for Specific Purposes, 26(3), 308-326.

Friginal, E. (2009). Threats to the sustainability of the outsourced call center industry in the Philippines: Implications for language policy. Language Policy, 8(1), 51.

Ghaill, M. M. A. (1996). Sociology of education, state schooling and social class: Beyond critiques of the New Right hegemony. British Journal of Sociology of Education, 17(2), 163-176.

Gonzaga, E. (2008). Globalization and becoming-nation: Subjectivity, nationhood and narrative in the period of global capitalism. Quezon City, Philippines: University of the Philippines Press.

Gonzales, W. D. W. (2017). Philippine Englishes. Asian Englishes, 19(1), 79-95.

Gonzalez, A. (1983). When does an error become a feature of Philippine English? In R. B. Noss (ed.), Varieties of English in Southeast Asia (pp. 150-172). Singapore: SEAMEO Regional Language Centre.

Gonzalez, A. (1976). Content in English language materials in the Philippines: A case study of cultural and linguistic emancipation. Philippine Studies, 24(4), 443-454. 
Gonzalez, A., \& Alberca, W. (1978). Philippine English of the Mass Media. Manila: Linguistic Society of the Philippines.

Heller, M. (2010). The commodification of language. Annual Review of Anthropology, 39, 101114.

Heron, T. (2008). Globalization, neoliberalism and the exercise of human agency. International Journal of Politics, Culture and Society, 20(1-4), 85-101.

Kachru, B. B. (1997). English is an Asian language. In M. L. S. Bautista (ed.), English is an Asian language: The Philippine context (pp. 1-23). Sydney: the Macquarie Library Pty. Ltd.

Kachru, B. B. (1988). The sacred cows of English. English Today, 4(4), 3-8.

Kachru, B. B. (1986). The alchemy of English: The spread, functions, and models of non-native Englishes. Urbana \& Chicago: University of Illinois Press.

Kleibert, J. M. (2015). Industry-academe linkages in the Philippines: Embedding foreign investors, capturing institutions? Geoforum, 59, 109-118.

Krady, M. M. (2006). Hybridity in cultural hybridization. Communication Theory, 12(3), 316339.

Kubota, R. (2015). Inequalities of Englishes, English speakers, and languages: A critical perspective on pluralist approaches to English. In R. Tupas (ed.), Unequal Englishes: The politics of Englishes today (pp. 21-41). Basingstoke: Palgrave Macmillan.

Lazzarato, M. (2009). Neoliberalism in action: Inequality, insecurity and the reconstitution of the social. Theory, Culture \& Society, 26(6), 109-133.

Lee, Jamie S. (2004) Linguistic hybridization in K-pop: discourse of self-assertion and resistance. World Englishes, 23(3), 429-50. 
Levy, D. L. (2005). Offshoring in the new global political economy. Journal of Management Studies, 42(3), 685-693.

Llamzon, T. A. (1986). Life cycle of New Englishes: restriction phase of Filipino English. English World-Wide, 7(1), 101-125.

Llamzon, T. A. (1969). Standard Filipino English. Manila: Ateneo de Manila University Press.

Lorente, B. P. (2018). Scripts of servitude: Language, labor migration and transnational domestic work. Multilingual Matters.

Lorente, B. (2012). The making of 'workers of the world': Language and the labor brokerage state. In A. Duchêne and M. Heller (eds.), Language in late capitalism: Pride and profit (pp. 183-206). London: Routledge.

Mahboob, A. \& Golden, R. (2013). Looking for native speakers of English: Discrimination in English language teaching job advertisements. Voices in Asia Journal, 1(1), 72-81.

Marasigan, E. (1980). The study of conversational and written uses of Pilipino-English. MA Thesis. Singapore: SEAMEO-RELC and University of Singapore.

Martinez, N. D. (1975). Standard Filipino English Pronunciation. National Book Store.

Martinez, N. D. (1972). An integrative approach to teaching and learning standard Filipino English pronunciation. Unpublished master's thesis, Ateneo de Manila University.

Moraña, M., Dussel, E., \& Jáuregui, C. A. (2008). Colonialism and its replicants. In M. Moraña, E. Dussel, \& C. A. Jáuregui (eds), Coloniality at large: Latin America and the postcolonial debate (pp. 1-22). Durham and London: Duke University Press.

Murphy, V. A. (2018). Commentary: Socio-economic status, young language learning, and the weapon to change the world. System, 73, 89-93.

Navera, G. S. (2018). The technicist framework and the teaching of speech communication in 
the Philippines. In Martin, I. P. (Ed.), Reconceptualizing English education in multilingual societies: English in the Philippines (pp. 140-152). New York: Springer.

Navera, G. S. (2011). 'WAR ON TERROR' IS A CURATIVE: Recontextualization and political mythmaking in Gloria Macapagal Arroyo's State of the Nation Addresses (2002-2004). Critical Inquiry in Language Studies, 8(4), 313-343.

Ndlovu-Gatsheni, S. J. (2013). The entrapment of Africa within the global colonial matrices of power: Eurocentrism, coloniality, and deimperialization in the twenty-first century. Journal of Developing Societies, 29(4), 331-353.

Nyamnjoh, F. B. (2012). 'Potted plants in greenhouses': A critical reflection on the resilience of colonial education in Africa. Journal of Asian and African Studies, 47(2), $129-154$.

Padios, J. M. (2018). A nation on the line: Call centers as postcolonial predicaments in the Philippines. Durham: Duke University Press.

Parakrama, A. (1995). De-hegemonizing language standards: Learning from (post) colonial Englishes about English. Basingstoke: Palgrave Macmillan.

Park, J. S-Y. (2010). Naturalization of competence and the neoliberal subject: Success stories of English language learning in the Korean conservative press. Journal of Linguistic Anthropology, 20(1), 22-38.

Parreñas, R. S. (2001). Servants of globalization: Women, migration and domestic work. Stanford: Stanford University Press.

Phillipson, R. (1996). Linguistic imperialism: African perspectives. ELT Journal, 50(2), 160167.

Platt, J. T., Weber, H., \& Ho, M. L. (1984). The New Englishes. London: Routledge \& Kegan 
Paul.

Pride, J. B. (1982). New Englishes. Rowley, MA: Newbury House.

Quijano, A. (2000). Coloniality of power, Eurocentrism and Latin America. Neplanta: Views from South, 1(3), 533-580.

Rampton, B. (2010). Social class and sociolinguistics. Applied Linguistics Review, 1, 1-21.

Ray, L. \& Sayer, A. (eds.) (1999). Culture and economic after the cultural turn. London, Thousand Oaks and New Delhi: SAGE.

Ray, L. \& Sayer, A. (1999). Introduction. In L. Ray and A. Sayer (eds.), Culture and economic after the cultural turn (pp. 1-24). London, Thousand Oaks and New Delhi: SAGE.

Robinson, W. I., \& Harris, J. (2000). Towards a global ruling class? Globalization and the transnational capitalist class. Science \& Society, 64(1), 11-54.

Rojek, C. \& Turner, B. (2000). Decorative sociology: Towards a critique of the cultural turn. The Sociological Review, 48(4), 629-648.

Rollock, N. (2014). Race, class and 'the harmony of dispositions'. Sociology, 48(3), 445-451.

Salonga, A. O. (2015). Performing gayness and English in an offshore call center industry. In R. Tupas (ed.), Unequal Englishes: The politics of Englishes today (pp. 130-142). Basingstoke: Palgrave Macmillan.

Salonga, A. O. (2010). Language and situated agency: An exploration of the dominant linguistic and communication practices in the Philippine offshore call centers (Doctoral dissertation). National University of Singapore.

San Juan Jr., E. (2009). Overseas Filipino Workers: The making of an Asian-Pacific diaspora. The Global South, 3(2), 99-129.

San Juan Jr., E. (2000). After postcolonialism: Remapping Philippines-United States 
confrontations. Lanham, Maryland: Rowman \& Littlefield.

Sayer, P. (2018). Does English really open doors? Social class and English teaching in public primary schools in Mexico. System, 73, 58-70.

Schirmer, D. B., \& Shalom, S. R. (Eds.). (1987). The Philippines reader: A history of colonialism, neocolonialism, dictatorship, and resistance. USA: South End Press.

Sercombe, P., \& Tupas, R. (Eds.). (2014). Language, education and nation-building: Assimilation and shift in Southeast Asia. Basingstoke: Palgrave Macmillan.

Sibayan, B. \& Gonzalez, A. (1996). Post-imperial English in the Philippines. In J. A. Fishman, A. W. Conrad, \& A. Rubal-Lopez, A. (Eds.), Post-imperial English: Status change in former British and American colonies, 1940-1990 (pp. 139-172). Berlin \& New York: Mouton de Gruyter.

Sklair, L. (1997). Social movements for global capitalism: the transnational capitalist class in action. Review of International Political Economy, 4(3), 514-538.

Song, J. (2018). English just is not enough!: Neoliberalism, class, and children's study abroad among Korean families. System, 73, 80-88.

Tabiola, H. (2015). Uncovering ideology in an ELT aid: The case of a recipient tertiary institution in the Southern Philippine. MA Thesis, Ateneo de Manila University.

Tabiola, H., \& Lorente, B. (2017). Neoliberalism in ELT aid: Interrogating a USAID ELT project in southern Philippines. In M. C. Flubacher \& A. Del Percio (eds.), Language, education and neoliberalism: Critical studies in sociolinguistics (pp. 122-139Bristol: Multilingual Matters.

Tayao, M. L. G. (2004). The evolving study of Philippine English phonology. World Englishes, 23(1), 77-90. 
Tay, M. (1991). Southeast Asia and Hong Kong. In J. Cheshire (ed.), English around the world: Sociolinguistic perspectives (pp. 319-332). Cambridge: Cambridge University Press.

Tinio, M. T. (2013). Nimble tongues: Philippine English and the feminization of labour. In L. Wee, R. B. H. Goh and L. Lim (eds.), The politics of English: Southeast Asia, Southeast Asia and the Asia Pacific (pp. 205-224). Amsterdam, The Netherlands: John Benjamins.

Thompson, K. (2002). Border crossings and diasporic identities: Media use and leisure practices of an ethnic minority. Qualitative Sociology, 25(3), 409-418.

Thrupp, M. (2001). Education policy and social class in England and New Zealand: An instructive comparison. Journal of Education Policy, 16(4), 297-314.

Tucker, G. R. (1968). Judging personality from language usage: a Filipino example. Philippine Sociological Review, 16(1/2), 30-39.

Tupas, R. (2015). Unequal Englishes: the politics of Englishes today. Basingstoke: Palgrave Macmillan.

Tupas, R. (2004). The politics of Philippine English: Neocolonialism, global politics, and the problem of postcolonialism. World Englishes, 23(1), 47-58.

Tupas, R., \& Salonga, A. (2016). Unequal Englishes in the Philippines. Journal of Sociolinguistics, 20(3), 367-381.

Tupas, R., \& Tabiola, H. (2017). Language policy and development aid: a critical analysis of an ELT project. Current Issues in Language Planning, 18(4), 407-421.

Urry, J. (2003). Global complexity. Cambridge: Polity Press.

Vincent, C. \& Ball, S. J. (2007). Making up the middle-class child: Families, activities and class dispositions. Sociology, 41(6), 1061-1077. 
Williams, J. C., Blair-Loy, M., \& Berdahl, J. L. (2013). Cultural schemas, social class, and the flexibility stigma. Journal of Social Issues, 69(2), 209-234.

On the campus "English only" signs are displayed to discipline students to converse only in English and not in their native tongues during class breaks. The campus thereby resembles call centre office environments, where the same signs are used. (p. 113) 